\title{
ALTERNATION OF HOST PLANTS AS A SURVIVAL MECHANISM OF LEAFHOPPERS Dilobopterus costalimai AND Oncometopia facialis (HEMIPTERA: CICADELLIDAE), VECTORS OF THE CITRUS VARIEGATED CHLOROSIS (CVC)
}

\author{
José Maria Milanez ${ }^{1,2,4}$; José Roberto Postali Parra ${ }^{3,4 *}$; Denise Cristina Magri ${ }^{4}$ \\ ${ }^{1}$ Graduate Student in Entomology - USP/ESALQ. \\ EPAGRI, C.P. 791 - CEP: 89901-970 - Chapecó, SC. \\ ${ }^{3}$ Depto. de Entomologia, Fitopatologia e Zoologia Agrícola - USP/ESALQ, C.P. 9 - CEP: 13418-900 - Piracicaba, SP. \\ ${ }^{4} \mathrm{CNPq}$ Fellow. \\ ${ }^{*}$ Corresponding author <jpparra@carpa.ciagri.usp.br>
}

\begin{abstract}
Dilobopterus costalimai (Young) and Oncometopia facialis (Signoret) are two of the most important species of citrus leafhoppers, vectors of bacterium Xylella fastidiosa which causes the Citrus Variegated Chlorosis (CVC) disease. To develop a rearing technique for these species under laboratory conditions, the egg laying preference and nymph development were studied in different breeding systems: Rangpur lime (Citrus limonia) and "falso boldo" (Vernonia condensata) as host plants. Trials were set up in a randomized block design with three treatments $(\mathrm{n}=8)$. Females of $D$. costalimai had particular preference for ovipositing on Rangpur lime leaves while $O$. facialis females placed a higher number of eggs on "falso boldo", but it did not differ statistically from the Rangpur lime. The nymphal viability of $D$. costalimai was null in Rangpur lime and $58 \%$ in "falso boldo". For $O$. facialis the nymphal viability was 25 and $78 \%$ in Rangpur lime and "falso boldo", respectively. "Falso boldo" is more suitable as a host plant to rear the two species of citrus leafhoppers. The alternation of host plants seems to be an important survival mechanism of the CVC-vector species, as shown in natural conditions.

Key words: biology, nutritional ecology, host preference

\section{ALTERNÂNCIA DE HOSPEDEIROS COMO MECANISMO DE SOBREVIVÊNCIA DAS CIGARRINHAS Dilobopterus costalimai E Oncometopia facialis (HEMIPTERA: CICADELLIDAE), VETORAS DA CLOROSE VARIEGADA DOS CITROS (CVC)}

\begin{abstract}
RESUMO: Dilobopterus costalimai (Young) e Oncometopia facialis (Signoret) são duas das mais importantes espécies de cigarrinhas dos citros, transmissoras da bactéria Xylella fastidiosa causadora da doença conhecida como Clorose Variegada dos Citros (CVC). Com o objetivo de se desenvolver uma técnica de criação destas espécies, em condições de laboratório, estudou-se a preferência por postura e o desenvolvimento ninfal, em diferentes sistemas de criação, tendo como plantas hospedeiras limão cravo (Citrus limonia) e falso boldo (Vernonia condensata). O delineamento experimental foi em blocos casualizados com três tratamentos e oito repetições. Fêmeas de $D$. costalimai tiveram acentuada preferência para ovipositar em folhas de limão cravo, enquanto que fêmeas de $O$. facialis colocaram maior número de ovos em falso boldo, embora não diferisse estatisticamente de limão cravo. A viabilidade ninfal da espécie D. costalimai foi nula em limão cravo e de $58 \%$ em de falso boldo. Para a espécie $O$. facialis a viabilidade ninfal foi de 25 e $78 \%$, em limão cravo e falso boldo, respectivamente, confirmando ser o falso boldo uma planta hospedeira mais adequada para a criação das duas espécies de cigarrinhas dos citros. Na natureza, a alternância de hospedeiros parece ser um importante mecanismo de sobrevivência das espécies vetoras da CVC.
\end{abstract}

Palavras-chave: biologia, ecologia nutricional, preferência hospedeira

\section{INTRODUCTION}

Since the late 1980s, when the Citrus Variegated Chlorosis disease (CVC) or "Amarelinho" was identified in groves of the producing regions of the state of Sao Paulo, a significant increase of the rate of infested plants and degree of severity of the disease took place, presently reaching $34.4 \%$ of the citrus area or 68 million trees with CVC symptoms. The disease is caused by bacterium Xylella fastidiosa, which develops on xylem vessels of infected plants (Paiva et al. 1996). Some leafhopper species of the family Cicadellidae have been 
identified as vectors of this bacterium in citrus plants in Brazil, among which species Dilobopterus costalimai and Oncometopia facialis (Roberto et al., 1996; Lopes et al., 1996).

In Brazilian conditions, little is known about the bioecological and nutritional aspects of the citrus leafhoppers, however, the variation of host plants in its eating system seems to be very important for the development of the immature and adult stages of this group of insects. Thus, Lopes et al. (1998) cited $D$. costalimai and $O$. facialis as species occurring in citrus and coffee areas and they suspected that they were a common vector of bacterium Xylella fastidiosa for both crops. Almeida \& Lopes (1999) verified that the mortality of the nymphal stage of species $D$. costalimai and $O$. facialis reared on the upper third part of citrus seedlings (sprouts) was 80.5 and $75.4 \%$, respectively, and over $66 \%$ of the mortality occurred on the first instar. Yamamoto \& Gravena (2000), while studying the populational abundance of citrus leafhoppers classified the species $D$. costalimai and $O$. facialis as accidentally occurring in citrus groves.

The free amino acids found in the sap of plants are the base diet of the leafhoppers feeding on the xylem or plant phloem, which determines the selection of the primary host plants and dispersion of leafhoppers in different habitats and times of the year (Russel et al. 1987, Andersen et al. 1993). For species Homalodisca coagulata the selection of host plants and the adult population were verified to be positively correlated with the concentration of a few amino acids found in standard plants regarding feeding, and the nymphs failed to develop successfully on the hosts preferred by the adults due to the fact that they cannot assimilate as efficiently as the adults the essential nutrients in nutritionally unbalanced plants (Brodbeck et al. 1990; 1995).

The aim of this work was to test the development and egg laying of species $D$. costalimai and $O$. facialis, under laboratory conditions, in rearing systems involving Rangpur lime and "falso boldo".

\section{MATERIAL AND METHODS}

In an incubator set at $25 \pm 2^{\circ} \mathrm{C}, \mathrm{RH} 60 \pm 10 \%$ and 14-hour photophase, carrying out two similar experiments evaluating the egg-laying preference and nymphal mortality for species Oncometopia facialis and Dilobopterus costalimai (Figure 1). Leafhopper couples were placed in rearing cage (containers), available in the market, on which side openings were made and sealed with a voil cloth. Openings were also made on the lids to allow the introduction of small tubes containing Rangpur lime and "falso boldo" seedlings (Figures 2 and 3 ). The tubes were supported by metal grids and then placed onto plastic trays $(35 \times 40 \times 80 \mathrm{~cm})$ containing a nutritive solution.
Each experiment had 3 treatments replicated 8 times. The treatments were: 1) rearing system using exclusively citrus (Rangpur lime) as a host plant; 2) rearing system, using exclusively "falso boldo" as a host plant; 3) rearing system combining "falso boldo" and citrus (Rangpur lime) as host plants. A randomized block design was performed and the results were submitted to analysis of variance and the means were compared by Tukey's test at $5 \%$ probability.

\section{RESULTS AND DISCUSSION}

Females of $D$. costalimai had a clear preference to oviposit on Rangpur lime leaves in comparison with "falso boldo" (Figure 4). In a free-choice situation, as in system 3, in which small tubes of Rangpur lime and "falso boldo" were placed in the same cage, the egg laying preference for Rangpur lime was also evident (Figure 5). That probably occurred because the egg laying is endophytic and the Rangpur lime leaf is more consistent and favors the introduction of the ovipositor by the female, which does not happen with the "falso boldo" leaf. That trend was not observed for species $O$. facialis, that is, there was no preference between hosts in the no-choice test (Figure 6). Under free-choice conditions the higher number of egg lays was observed in citrus (Figure 7). This variation can be related with the fact that the 0 . facialis egg laying is not endophytic.

The "falso boldo" seedlings offered best conditions for the development of $D$. costalimai nymphs, with the reduction of mortality to about $42 \%$, while in the system in which the nymphs fed exclusively on citrus leaves the mortality was $100 \%$ (Figure 8 ). These data are in accordance with those found by Almeida \& Lopes (1999), who observed a high mortality of nymphs of $D$. costalimai and $O$. facialis reared on citrus cuttings.

For $O$. facialis the results were higher, that is, the nymphal viability was $78 \%$ in the rearing system using exclusively "falso boldo" seedlings and $25 \%$ when the rearing system had only citrus seedlings (Figure 9). Therefore, $O$. facialis nymphs manage to feed and develop on citrus seedlings, unlike the $D$. costalimai nymphs. Although it is not the goal of this study to quantify the hosts under the nutritional point of view, specific chemical compounds, as the amino acid, for instance, are likely to be present in the "falso boldo" plant, ensuring a better development for leafhopper nymphs as observed for the Homalodisca coagulata nymphs that need a distinguished feeding with amino acids, found in different hosts in order to develop (Brodbeck et al., 1990; 1995).

Under field conditions, the presence of adults and egg lays in citrus plants are observed, and the nymphs are scarce. This suggests that citrus are not primary but occasional hosts, with other alternative host plants important to the development of the different leafhopper species, as it is the case of the "falso boldo", 
A

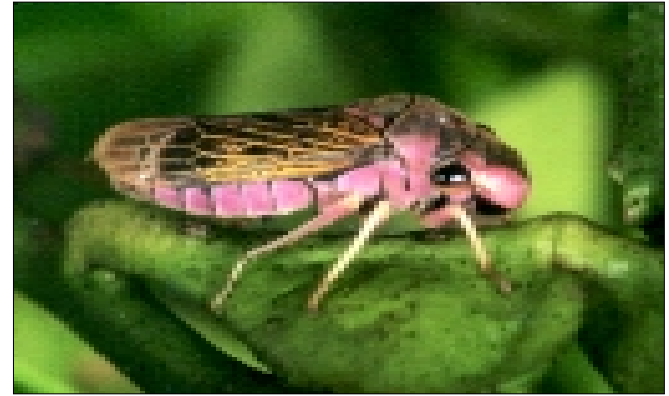

B

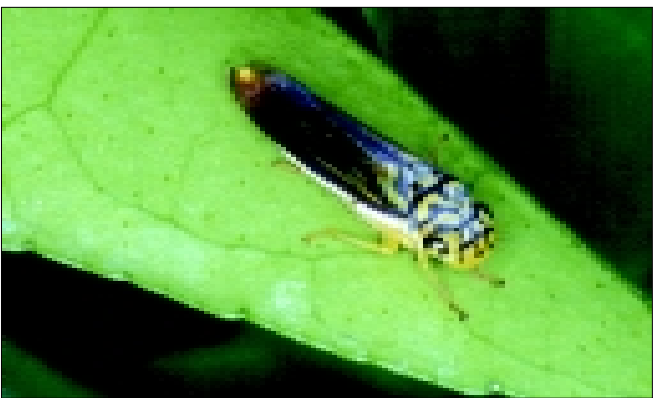

Figure 1 - Oncometopia facialis (A) and Dilobopterus costalimai (B)

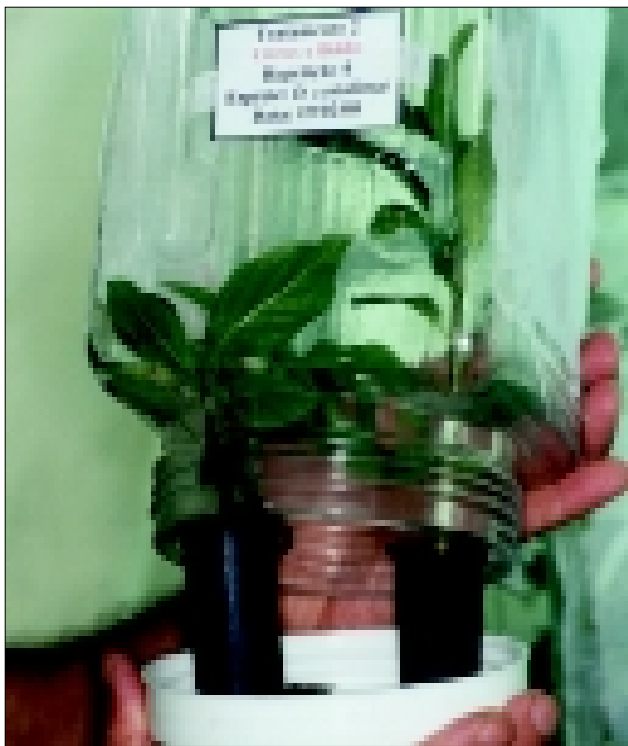

Figure 2 - Rearing cage.

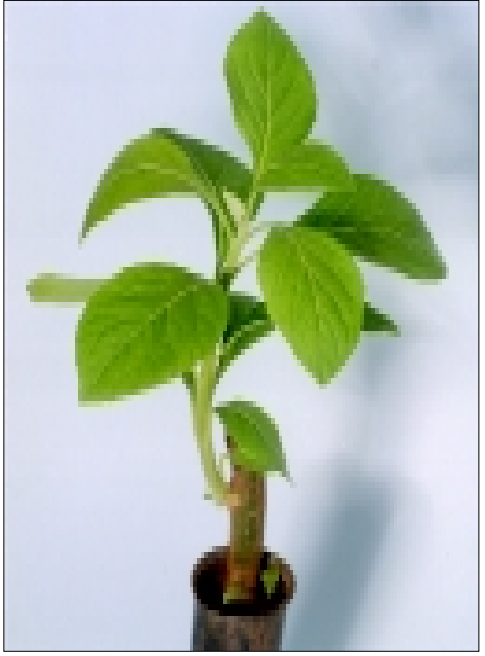

Figure 3 - "Falso boldo" plant.

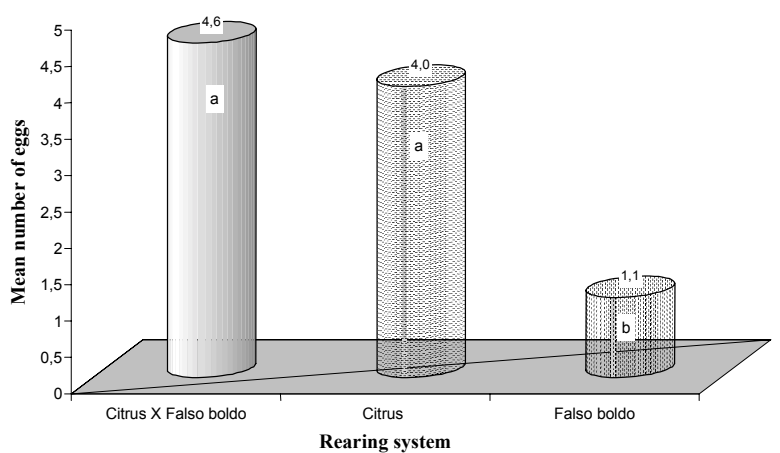

Figure 4 - Egg laying of Dilobopterus costalimai in the different rearing systems tested.

Means followed by the same letter do not differ by Tukey's test at a $5 \%$ probability level.

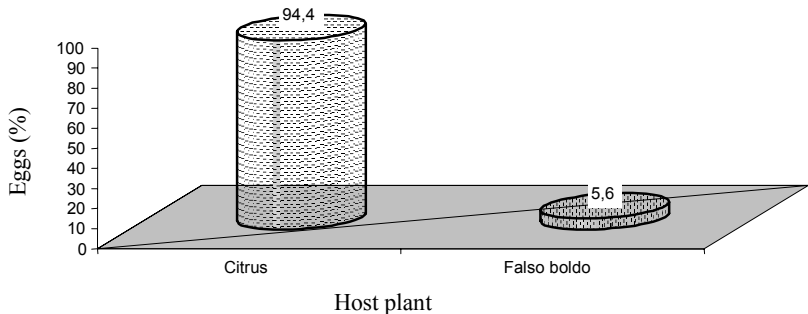

Figure 5 - Percentage egg laying of Dilobopterus costalimai in citrus and "falso boldo" seedlings in the citrus $\mathrm{x}$ "falso boldo" system.

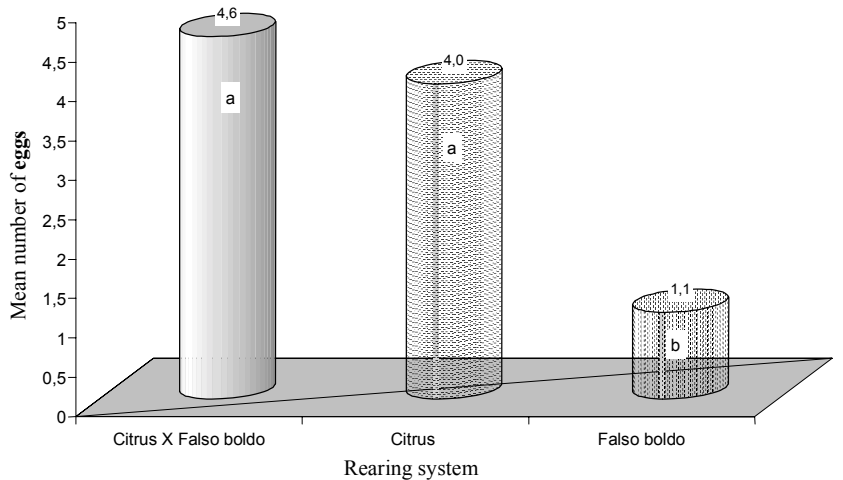

Figure 6 - Egg laying of Oncomtopia facialis in different rearing systems tested.

Means followed by the same letter do not differ by Tukey's test at a $5 \%$ probability level.

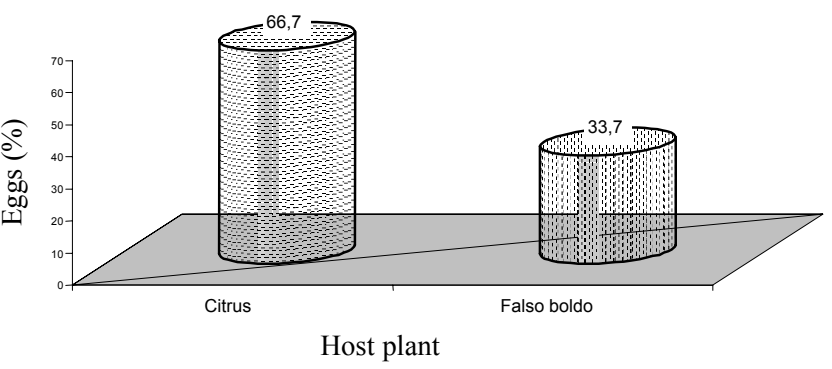

Figure 7 - Percentage egg laying of Oncometopia facialis in citrus and "falso boldo" seedlings in the citrus x "falso boldo" system. 


\section{REFERENCES}

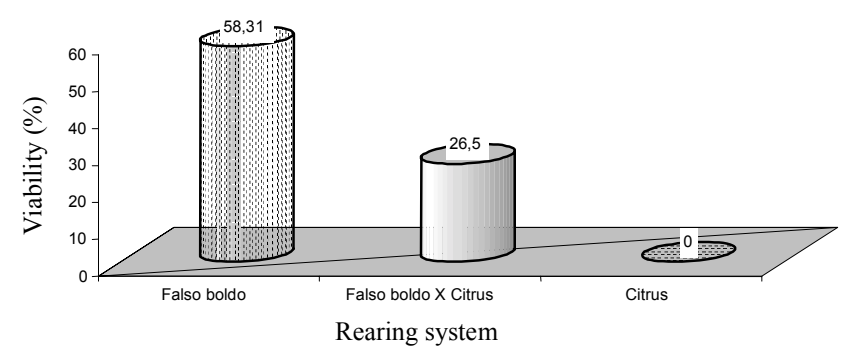

Figure 8 - Viability (\%) of the nymphal stage of Dilobopterus costalimai in the different rearing systems tested.

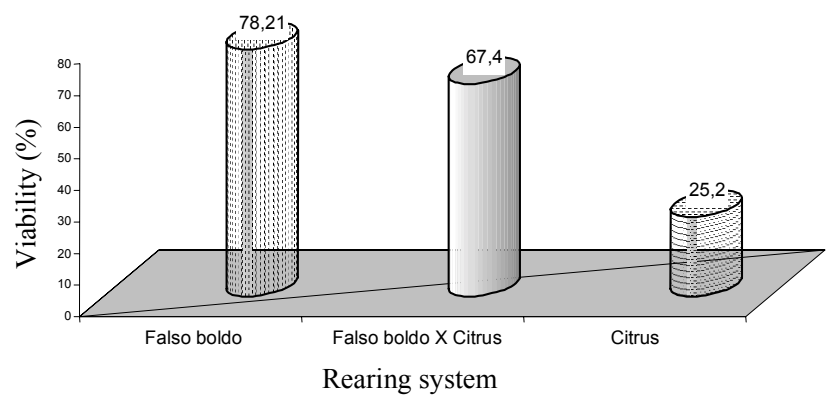

Figure 9 - Viability (\%) of the nymphal stage of Oncometopia facialis in the different rearing systems tested.

reinforcing the hypothesis of Yamamoto \& Gravena (2000), who classified leafhoppers as occasionally occurring in citrus groves. Such discovery may open new perspectives in the control of CVC-vector leafhoppers. "Falso boldo" and other host plants could contain substances that might, once identified and synthesized, function as attractants of these species and be incorporated to Pest Management. Programs Alternation of host plants seems to be an important mechanism of survival of the CVC-vector leafhoppers.

\section{ACKNOWLEDGEMENT}

To biologist Heraldo Negri de Oliveira, technician of the Department of Entomology, Plant Pathology and Agricultural Zoology of USP/ESALQ, for the photographic work.
ALMEIDA, P.P.; LOPES, J.S. Desenvolvimento de imaturos de Dilobopterus costalimai Young, Oncometopia facialis (Signoret) e Homalodisca ignorata Melichar (Hemiptera: Cicadellidae) em citros. Anais da Sociedade Entomológica do Brasil, v.28, p.179-182, 1999.

ANDERSEN, B.V.; BRODBECK, B.V.; MIZEL III, R.F. Diurnal variations of amino acids and organic acids in xylem fluid from Lagerstroemias indica Physiologia Plantarum, v.89, p.783790, 1993.

BRODBECK, B.V.; MIZELL III, R.F.; ANDERSEN, P.C. Differential utilization of nutrients during development by the xylophagous leafhopper, Homalodisca coagulata. Entomologia Experimentalis et Applicata, v.75, p.279-289, 1995.

BRODBECK, B.V.; MIZELL III, R.F.; FRENCH, W.J.; ANDERSEN, P.C.; ALDRICH, J.H. Amino acids as determinants of host preference for xylem feeding leafhopper, Homalodisca coagulata (Homoptera: Cicadellidae). Oecologia, v.83, p.338345, 1990.

LOPES, J.R.S. Mecanismos de transmissão de Xylella fastidiosa por cigarrinhas. Laranja, v.17, p.79-92, 1996.

LOPES, J.R.S.; GIUSTOLIN, T.A.; MARUCCI, R.C.; TAKIMOTO, J.K.; MENDES, M.A. Composição de espécies de cigarrinhas (Hemiptera, Auchenorryncha) em café e citros na região de Bebedouro, SP. In: CONGRESSO BRASILEIRO DE ENTOMOLOGIA, 28.; ENCONTRO NACIONAL DE FITOSSANITARISTAS, 7., Rio de Janeiro, 1998. Resumos. Rio de Janeiro, 1998, p.615.

PAIVA, P.E.B.; SILVA, J.L.; GRAVENA, S.; YAMAMOTO, P.T. Cigarrinhas de xilema em pomares de laranja do Estado de São Paulo. Laranja, v.17, p.41-54, 1996.

ROBERTO, S.R.; COUTINHO, A.; LIMA, J.E.O.; CARLOS, E.F. Transmissão de Xylella fastidiosa pelas cigarrinhas Dilobopterus costalimai e Oncometopia facialis (Hemiptera: Cicadellidae) em citros. Fitopatologia Brasileira, v.21, p.517-518, 1996.

RUSSELL, F.M.; FRENCH, W.J. Leafhopper vectors of phony peach disease: Feeding site preference and survival on infected and uninfected peach, and seasonal response to selected host plants. Journal of Entomology Science, v.22, p.11-22, 1987.

YAMAMOTO, P.T.; GRAVENA, S. Espécies e abundância de cigarrinhas e psilídeos (Homoptera) em pomares de citros. Anais da Sociedade Entomológica do Brasil, v.29, p.169176, 2000.

Received November 14, 2000 